\title{
Green light for twin lab
}

THE plan to found a biotechnology organization on behalf of developing countries, masterminded during the past two years by the United Nations Industrial Development Organization (UNIDO), moved one notch ahead last week. The preparatory committee of the International Centre for Genetic Engineering and Biotechnology, meeting in Vienna, heard for the first time what funds the two host countries, India and Italy, are willing to commit. The plan now is that a project leader and a scientific committee should be identified by the committee's next meeting in December.

Opinions are divided about the pace of events beyond that. The two years already spent on the discussion of the project are not thought excessive by the yardsticks of international diplomacy, and because the end-product will be a free-standing international organization to which the 33 member states will be bound by a convention with the legal force of a treaty.

In many cases, the project became tangible only at the beginning of this year, with the decision that the new centre would have two components, one in Italy (Trieste) and one in India (Delhi).

The funds now allocated by the two host governments are substantial but far from sufficient to keep the project going. The Government of India last week offered \$5 million towards the cost of the first five years' work at the Delhi site, supplemented by an offer of $\$ 8.2$ million from the Italian Government, which has also promised \$4 million and 13,000 million lire towards the cost of five years' work at Trieste.

The two governments will also contribute towards the cost of equipment (Rs 15 million and 58 million lire for India and Italy respectively). India plans to spend Rs 72 million on land and buildings near Delhi, while Italy will provide a building at Trieste at a token rental.

These bids will demonstrate the seriousness of the two hosts and also serve to encourage the others, as at a charity auction. Whether the other potential contributors will arrive at Vienna with enough promissory notes is, however, less certain. Some will wish to know what people are chosen in the next three months, others the colour of their fellow-members' money, while doubts persist about the decision to split the centre into two components.

A further difficulty is that the centre is planned to be the hub of an international network of "associated centres" that will be nationally located so as to assist with training and exploitation. The obvious danger is that member governments will prefer to commit what funds they can afford to the development at home.

There are also further decisions to be made about the division of work between Delhi and Trieste. The Indian centre will be concerned with developments in agriculture and human health, the Italian with the application of biotechnology in the chemical industry, energy and the like. But where (and how) the dividing line will be drawn is still to be decided in detail.

\section{Badgers at bay}

THE conflict between British farmers and wildlife interests over the badger as a source of bovine tuberculosis will persist, last week's report on the subject from the Ministry of Agriculture, Fisheries and Food (MAFF) notwithstanding. The issue is contentious because the badger is one of the largest native mammals surviving in southern Britain and because wildlife interests dispute the reality of the connection between badgers and bovine tuberculosis. Under present policy, badgers are protected under the Badger Act except in areas (mostly in the south-west) where infection by Mycobacterium bovis and badgers coexist, as recommended by Lord Zuckerman in 1980.

The latest report on Bovine Tuberculosis in Badgers, the eighth to be published, extends the study of captured badgers up to the end of 1983 . It says that 13 per cent of 6,000 carcasses examined at MAFF laboratories between 1971 and 1983 show traces of infection, a higher rate of incidence than in any other common British animal.

But do badgers communicate the disease to cattle? If so, then it is presumably via faeces. Tests for M.bovis in faeces over the same eleven-year period were positive in 3 per cent of cases. The evidence implicating the badger population as a reservoir for M.bovis remains circumstantial and rests on the coincidence of outbreaks of bovine tuberculosis with concentrations of badgers. The case against badgers is strong but not watertight.

There are, unfortunately, no reliable estimates of the size of Britain's badger population. It is unlikely, the World Wildlife Fund believes, that the species is threatened nationally by culling.

Live trapping has now replaced gassing as the chief method of controlling tuberculosis in badgers, in spite of the extra cost. All cattle are tested regularly for bovine tuberculosis and those reacting to the tests are slaughtered. Research into the link between bovine tuberculosis and badgers and control of the disease continues.

Meanwhile, MAFF has announced a further comprehensive review, as recommended by the Zuckerman report, of the problem of badgers and bovine tuberculosis, to be carried out by a three-man team under Professor G.M. Dunnet (University of Aberdeen), and the ministry now promises that the new findings will be made public.

Marcus Chown
Sellafield

BNFL on

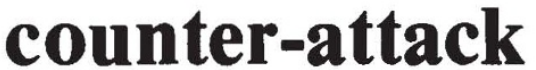

BRITISH Nuclear Fuels Ltd (BNFL), the focus of public criticism during the past year over its waste-disposal indiscretions, has hit back at its critics in its annual report, Radioactive Discharges and the Monitoring of the Environment, 1983. The company hopes that data published in the report will draw the debate on its conduct out of the emotional arena and back into the forum of facts. But this seems unlikely while the argument about high leukaemia incidence near BNFL's Sellafield reprocessing plant continues.

BNFL reports that, during 1983, the quantity of liquid waste discharged from its Sellafield site into the Irish Sea was reduced substantially, continuing the trend of recent years. The total beta discharge was cut by 50 per cent compared with the 1982 level and the alpha discharge was down by 30 per cent. These reductions were achieved despite the contamination of a 15-mile stretch of the Cumbrian coastline, near Sellafield, in 1983 after the accidental transfer of plant washings to a sea tank on site, for which the company is now to be prosecuted. BNFL says that the total radioactivity released as a consequence of this error was negligible, amounting, over an eight-month period, to less than onetenth of a curie $\left(1\right.$ curie $=3.7 \times 10^{10}$ disintegrations per second). This is to be compared with Sellafield's routine beta discharge in 1983 of 67,000 curie.

BNFL concedes that the contaminated beaches seriously damaged public confidence in the company. To restore that confidence, it is to step up its research efforts to cut liquid discharges to "essentially zero". $£ 190$ million is already earmarked for this purpose which will, of course, require an alternative disposal route, most probably to a land site. The company stresses, though, that it now operates well within the government's limits for the dumping of liquid waste.

BNFL has continued its programme of monitoring the environment during 1983. Shellfish eaters near the Sellafield plant have been identified as potentially at risk from radioactive contamination, but tests have verified that their exposure amounts to about one half of the annual limit recommended for members of the public by the International Commission on Radiological Protection (ICRP). According to the report, no other group in the vicinity of any other BNFL installation receives an annual dose even close to this level. These findings are confirmed by an independent study carried out by the Directorate of Fisheries Research of the Ministry of Agriculture, Fisheries and Food (Radioactivity in Surface and Coastal Waters of the British Isles, 1982).

Marcus Chown 